ANETA JUDZIŃSKA

Uniwersytet im. Adama Mickiewicza

w Poznaniu

\title{
NIEKONWENCJONALNA WALKA ZE STRESEM - KONTEKSTY I KULTUROWE UWARUNKOWANIA
}

ABSTRACT. Judzińska Aneta, Niekonwencjonalna walka ze stresem - konteksty i kulturowe uwarunkowania [Unconventional Battle with Stress - Contexts and Cultural Determinants]. Studia Edukacyjne nr 35, 2015, Poznań 2015, pp. 131-147. Adam Mickiewicz University Press. ISBN 978-83-232-2904-9. ISSN 1233-6688. DOI: $10.14746 /$ se.2015.35.7

The article seeks to investigate the contemporary, unconventional strategy of dealing with stress in Poland. Moreover, it represents the quintessence of various widespread tendencies of eliminating stress factors. The author examines specific remedial methods by its qualification according to the degree of conventionality and the influence on the health status. The study is extended by a sociocultural aspect which implies the culture of adrenalin and risk.

Key words: stress, ways of dealing with stress, unconventional strategies, risk culture

\section{Wprowadzenie}

Zjawisko stresu poddawane jest wielowymiarowej analizie ze względu na charakter oddziaływań badawczych, adekwatnych dla danej dziedziny nauki: medycyny, psychologii czy biologii. Nie dziwi więc fakt istnienia licznych definicji, obrazujących $w$ mniejszym lub większym stopniu owe zagadnienie. Jednakże, za prekursora studiów nad stresem psychicznym i związanych z nim biochemicznych reakcji ustroju uważa się Hansa Selye, który w latach trzydziestych XX wieku dokonał odkrycia dotyczącego fizjologicznego wymiaru stresu oraz mechanizmu jego działania w organizmie ludzkim ${ }^{1}$. Zdaniem badacza, "stres jest nieswoistą reakcją organizmu na

${ }^{1}$ W. Łosiak, Psychologia stresu, Warszawa 2008, s. 9-10. 
wszelkie stawiane mu żądanie" 2 . Przykładem wspomnianych $\mathrm{w}$ definicji żądań mogą być te najbardziej podstawowe związane $\mathrm{z}$ ochroną przed wirusami, bakteriami, a więc związane z naturalną barierą ochronną organizmu, po bardziej złożone związane z deprywacją potrzeb. Jednocześnie autor przytoczonej definicji wskazuje, że wskutek silnego pobudzenia $w$ organizmie zostaje aktywowany „GAS - zespół wywołany różnymi szkodliwymi czynnikami, (...) ogólny zespół przystosowania lub zespół stresu biologicznego", którego elementarnym zadaniem jest doprowadzenie organizmu do odzyskania równowagi wewnątrzustrojowej ${ }^{3}$. Analizując treść definicji utworzonych w świetle współczesnych badań, można zaobserwować ideologiczną ciągłość w zakresie koncentracji na poszczególnych aspektach sytuacji stresowej, w szczególności w wymiarze fizjologicznym. Jak podkreśla Władysław Łosiak, stres to:

zespół procesów obejmujących negatywne emocje i szereg zmian fizjologicznych (...) pojawiający się $\mathrm{w}$ reakcji na działanie wszelkiego typu niekorzystnych dla podmiotu czynników, urazów psychicznych, niepowodzeń, zagrożenia czy zranienia lub szoku termicznego ${ }^{4}$.

Uwagę badacza zwracają tutaj komponenty zaburzające równowagę ustroju. Utożsamiane są one niekiedy $\mathrm{z}$ pojęciem chaosu. $\mathrm{W}$ momencie pojawienia się czynnika stresogennego ograniczeniu ulegają zarówno zasoby behawioralne, jak i somatyczne, utrudniając tym samym radzenie sobie z napotkanymi trudnościami. Natomiast George D. Bishop na podstawie definicji utworzonej przez Richarda Lazarusa i Susan Folkman zauważa, że stres to

transakcja zachodząca między jednostką a otoczeniem, obejmująca ocenę wyzwań stawianych przez daną sytuację oraz zasobów radzenia sobie z nią, a także psychologiczne i fizjologiczne reakcje na tak oceniane wyzwania 5 .

W tej koncepcji stres ujmowany jest jako proces. Można więc stwierdzić, że charakterystycznym komponentem będzie rozciągłość w czasie i długotrwałość jego oddziaływań. Autor w przejrzysty i klarowny sposób wskazuje na zjawisko interakcji, jakie zachodzi pomiędzy człowiekiem a jego środowiskiem życia. Istotną rolę odgrywa tutaj nie sam bodziec, lecz jego adekwatna (subiektywna) interpretacja. Szczególną uwagę zwraca się więc

\footnotetext{
2 H. Selye, Stres okiełznany, przekł. Tomasz Zalewski, Warszawa 1977, s. 25.

3 Tamże, s. 35.

${ }^{4}$ J. Siuta, Stownik psychologii, Kraków 2005.

${ }^{5}$ G.D. Bishop, Psychologia zdrowia: zintegrowany umyst i ciało, Warszawa 2000, s. 180.
} 
na uruchomienie sfery umysłowej (psychologicznej) i biologicznej, rozumianej w kontekście zasobów energetycznych organizmu.

Stres, stanowiąc nieodzowny element ludzkiej egzystencji, bez względu na zakres i intensywność, z jaką oddziałuje na człowieka, implikuje w jego organizmie określone reakcje stanowiące o indywidualnych predyspozycjach oraz umiejętnościach radzenia sobie $\mathrm{w}$ sytuacjach problemowych (rozumianych tutaj jako podjęcie określonego działania lub jego brak). Najbardziej efektywnym przejawem akceptacji obecności stresorów w życiu codziennym będzie więc internalizacja oraz wypracowanie adekwatnych strategii zmierzających do ich minimalizowania lub/i całkowitej eliminacji. Jak podkreśla Irena Heszen-Niejodek, każda jednostka ma specyficzny, zsynchronizowany ze swoimi potrzebami i możliwościami sposób/sposoby eliminacji stresorów. „Styl ten jest traktowany jako właściwość indywidualna człowieka o statusie cechy osobowości"6.

Dokonując próby charakterystyki podejmowanych przez człowieka specyficznych strategii radzenia sobie ze stresem, warto przywołać psychologiczne koncepcje, stanowiące trzon wszelkich oddziaływań zaradczych, $\mathrm{w}$ literaturze przedmiotu określane jako style radzenia sobie ze stresem. Pełnią one funkcję nadrzędną, determinując tym samym wybór określonej metody redukowania bodźców stresowych. Odwołując się do podziału utworzonego przez Suzanne M. Miller, skonstruowanego na podstawie założenia klasycznej psychoanalizy, wyróżnia się dwa style: „pierwszy z nich polega na koncentracji uwagi na stresorze i/lub własnej reakcji”, podczas którego jednostka podejmuje działania zmierzające do wyjaśnienia sytuacji stresowej. Można więc wnioskować, że ma ona takie zasoby poznawcze i intelektualne, umożliwiające jej podjęcie czynności bezpośrednio zmierzających do rozwiązania zdarzenia, które budzi napięcie. Drugi natomiast definiowany jest przez autorkę jako „odwrócenie uwagi od stresora i własnych reakcji". Jego zasadniczym założeniem jest całkowicie intelektualne i fizyczne, swoiste wyizolowanie się od zdarzenia, które wywołało lęk, niepokój, czy zdenerwowanie. Wówczas osoba podejmuje czynności zastępcze poprzez „angażowanie się w bezstresowe formy aktywności”. Owe aktywności mogą być niekiedy znacznie zróżnicowane pod względem poziomu konwencjonalności oraz konsekwencji zdrowotnych ${ }^{7}$. Warto zatem nieco bardziej wnikliwie przeanalizować te strategie, które wykraczają poza granice norm prawnych, moralnych bądź/i zdrowotnych.

${ }^{6}$ I. Heszen-Niejodek, Styl radzenia sobie ze stresem jako indywidualna zmienna wptywajaca na funkcjonowanie w sytuacji stresowej, [w:] Osobowość a ekstremalny stres, red. J. Strelau, Gdańsk 2004, s. 238.

7 Tamże. 


\section{Niekonwencjonalne strategie radzenia sobie ze stresem}

Zagadnienie dotyczące niekonwencjonalnych strategii radzenia sobie ze stresem mieści w sobie szereg zróżnicowanych zachowań, które w konsekwencji prowadzą do wykształcenia $\mathrm{w}$ organizmie mechanizmu uzależniania. Klasyfikacja ICD-10 definiuje uzależnienie jako

zespół wystąpienia różnych zjawisk na poziomie biochemii, fizjologii, psychiki (zwłaszcza procesów poznawczych) i zachowania związanego z przyjmowaniem substancji psychoaktywnych lub uporczywego wykonywania pewnych czynności. Głównym objawem uzależnienia jest przemożne, często odczuwane jako nie do odparcia, pragnienie przyjęcia określonego środka psychoaktywnego lub wykonywania pewnych czynności ${ }^{8}$.

Za cechę charakterystyczną można więc uznać bezkompromisowe poddanie się jednostki nałogowemu działaniu, które stanowi niejako priorytet i wyznacza kierunek oraz cel dalszej aktywności. Tym samym, ogranicza autonomię i racjonalność, czego konsekwencją jest całkowita lub częściowa utrata kontroli nad własnym życiem. Biorąc pod uwagę współczesne klasyfikacje przyjęte przez międzynarodowe ośrodki badawcze, nie sposób wymienić i opisać wszystkich form i rodzajów uzależnień ${ }^{9}$. Główne kryterium podziału stosowane przez specjalistów dotyczy dwóch form aktywności: uzależnienia od substancji odurzających oraz uzależnienia od zachowania ${ }^{10}$. Można więc mówić m.in. o uzależnieniach od komputera, hazardu, seksu, jedzenia czy zakupów. Odwołując się jednak do wyników badań zawartych w literaturze przedmiotu, analizie poddałam tylko te zjawiska, które występują $\mathrm{w}$ populacji $\mathrm{z}$ największą częstotliwością, a mianowicie: alkoholizm, narkomania, nikotynizm oraz pracoholizm ${ }^{11}$.

\section{Alkoholizm}

Znany, polski przedstawiciel psychiatrii - Antoni Kępiński podkreśla, że współczesny człowiek w obliczu sytuacji trudnej czy kryzysowej „zwykle najpierw sam próbuje zredukować napięcie nerwicowe i niepokój”. Dopiero

${ }^{8}$ A. Augustynek, Jak walczyć z uzależnieniami ? Warszawa 2011, s. 26.

9 Zob. L. Cierpiałkowska, Oblicza wspótczesnych uzależnień, Poznań 2008; Z. Madeja, Uzależnienia od substancji psychoaktywnych, przedmiotów, czynności i osób: analiza kulturowo-spoteczna, filozoficzno-aksjologiczna, psychobiologiczna, psychopatologiczna, neuropsychologiczna zjawisk i procesów etiopatogenezy uzależnień oraz ich terapii, t. 1, Koszalin 2008.

${ }^{10}$ I. Pospiszyl, Patologie spoteczne, Warszawa 2008, s. 125.

${ }_{11}$ A. Augustynek, Jak walczyć z uzależnieniami, s. 6. 
kiedy własne „sposoby autoterapii" zawiodą, przekształcają się w przesłankę świadczącą (niekiedy) o konieczności skorzystania z pomocy specjalisty. Jedną z najbardziej znanych i popularnych metod samodzielnego radzenia sobie ze stresem jest zażywanie alkoholu. Autor wykazuje silną zależność występującą pomiędzy stresem i alkoholizmem ${ }^{12}$. Zgodnie z klasyfikacją ICD-10, zespół uzależnienia alkoholowego definiowany jest jako

całokształt zjawisk fizjologicznych, behawioralnych i poznawczych, w którym dominują aspekty związane z przyjmowaniem środków psychoaktywnych ponad innymi dążeniami i celami, kiedyś wartościowymi dla osoby ${ }^{13}$.

Efekty zaaplikowania owej substancji do organizmu przynoszą natychmiastową niemal ulgę $\mathrm{w}$ emocjonalnym oraz fizycznym napięciu. „Łagodne intoksykacje alkoholem powodują odprężenie i nastrój beztroski. Zazwyczaj efekt ten uważa się za korzystny, przyjemny i rozluźniający napięcie"14. Psychologiczną egzemplifikację owego fenomenu stanowi hipoteza o redukcji napięcia przez alkohol (tension - reduction hypothesis - TRT) oraz uszczegóławiająca ją hipoteza o tłumieniu przez alkohol odpowiedzi na stres (stressresponse dampening - SRD) ${ }^{15}$. Syntetyzując powyższe koncepcje, można w znacznym uproszczeniu - zaznaczyć, że w umiarkowanej dawce $(0,75$ $1,3 \mathrm{~g} / \mathrm{kg}$ masy ciała) ${ }^{16}$ alkohol reguluje (tłumi) zbyt wysoki - w przypadku sytuacji stresowej - poziom fizjologicznego i psychicznego napięcia, oddziałując na procesy biochemiczne zachodzące w mózgu. Jego farmakologiczne funkcje związane są z aktywacją neuroprzekaźników odpowiedzialnych za hamowanie zróżnicowanych procesów zachodzących w ośrodkowym układzie nerwowym. Najistotniejszą rolę spełnia neuroprzekaźnik GABA, który powoduje "spowolnienie i hamowanie czynności ruchowo-lokomocyjnych oraz redukcję lęku (działanie anksjolityczne), podobnie jak inne środki $\mathrm{z}$ grupy nasennych". W konsekwencji prowadzi to do stłumienia reakcji stresowej bezpośrednio po jej zaistnieniu bądź tuż przed jej wystąpieniem ${ }^{17}$.

Wyniki badań Małgorzaty Dragan oraz Mai Lis-Turlejskiej z 2007 roku, przeprowadzone w grupie 4582 osób uzależnionych od alkoholu (75\% mężczyzn), ujawniły, że $81 \%$ respondentów definiuje swoje uzależnienie jako odpowiedź na niemożność poradzenia sobie z traumatycznym, stresującym

12 J. Terelak, Człowiek $i$ stres, s. 278-279.

${ }^{13}$ L. Cierpiałkowska, M. Ziarko, Psychologia uzależnień - alkoholizm, Warszawa 2010, s. 89.

14 Z. Madeja, Uzależnienia od substancji psychoaktywnych, s. 257.

${ }^{15}$ L. Cierpiałkowska, M. Ziarko, Psychologia uzależnień - alkoholizm, s. 150.

16 Badania Fromme i D’Amico wykazały, że spożycie większych dawek powoduje rozdrażnienie, prowadząc nawet do agresji. Tamże, s. 155.

17 Tamże, s. 150. 
wydarzeniem życiowym ${ }^{18}$. Zjawisko alkoholizmu w społeczeństwie polskim prezentuje się jako problem występujący z dużą częstotliwością, ponieważ dotyczy około 3,5 mln przedstawicieli ${ }^{19}$. U osoby spożywającej istnieje przeświadczenie, że $\mathrm{w}$ ten sposób zapomni o swoich problemach i uzyska stan odprężenia, rozluźnienia. Przyjmuje to postać pewnego rodzaju psychicznej ucieczki od stresującego wydarzenia. Alkohol stanowi więc substytut poczucia bezpieczeństwa, które $u$ osób sięgających po niego zostało utracone na skutek stresujących wydarzeń życiowych.

Wzrastająca zależność i niczym nieograniczona potrzeba spożycia owej substancji prowadzi do kształtowania się mechanizmu błędnego koła, o którym nieco dokładniej pisze Irena Pospiszyl. Badaczka, odwołując się do psychologicznego mechanizmu warunkowania podkreśla, że „skojarzenie faktu redukcji napięcia po wypiciu alkoholu powoduje następnie świadome sięganie po alkohol w sytuacji, w której jednostka spodziewa się takiego właśnie efektu" ${ }^{20}$. Staje się więc dla człowieka standardową strategią radzenia sobie w sytuacji trudnej, stresowej. Można zatem wnioskować, że chęć spożycia alkoholu wiąże się z chwilowym tylko odwróceniem uwagi od nurtującego problemu. Dając złudne poczucie bezpieczeństwa, wytwarza jednocześnie silną potrzebę ponownego, coraz częstszego zażycia owej substancji21.

\section{Narkomania}

Jak wskazuje Stownik psychologii,

narkomania zgodnie $\mathrm{z}$ obowiązującą w Polsce ustawą o przeciwdziałaniu narkomanii, oznacza stałe lub okresowe używanie w celach niemedycznych środków odurzających lub substancji psychotropowych albo środków zastępczych, w wyniku czego może powstać uzależnienie od nich. W definicji Światowej Organizacji Zdrowia narkomania utożsamiana jest $\mathrm{z}$ uzależnieniem i traktuje się ją jako zespół zależności lekowej22.

Zatem, zjawisko narkomanii postrzegane w kontekście wtórnej konsekwencji nadużywania substancji farmakologicznych, bezprecedensowo wpisuje się $\mathrm{w}$ tradycyjną optykę nieaprobowanych społecznie praktyk. Wpięty

${ }_{18}$ M. Shevlin, K. McGuigan, Final Report, Mediating effects of mental health problems in the stress alcohol relationship, http://alcoholresearchuk.org/downloads/finalReports/AERC_ FinalReport_0077.pdf, [dostęp: 03.06.2014].

${ }^{19}$ A. Augustynek, Jak walczyć z uzależnieniami? s. 29.

20 I. Pospiszyl, Patologie społeczne, s. 144.

${ }^{21}$ B.T. Woronowicz, Uzależnienia: geneza, terapia, powrót do zdrowia, Warszawa 2009, s. 11-35.

22 J. Siuta, Stownik psychologii. 
w kulturowe standardy wizerunek narkomana może ukazywać się znacznej części odbiorców w formie nad wyraz zniekształconej: osoby pozbawionej wszelkich środków do życia, zaniedbanej zarówno w aspekcie materialnym, jak i społecznym, przemieszczającej rozległe, ciemne korytarze nizin społecznych. Chcąc wyzbyć się wszelkiej generalizacji, warto wspomnieć o jednostkach, w życiu których wszechobecny stres doprowadził do wykształcenia się niekonwencjonalnego sposobu poradzenia sobie z nim. Wspomaganie organizmu narkotykami miękkimi w przekonaniu tychże osób pozwala sprostać wymogom życia codziennego zarówno zawodowego, jak i rodzinnego ${ }^{23}$.

Jak wskazuje współczesna literatura, nad wyraz popularnym środkiem wśród osób zażywających substancje psychoaktywne są opioidy. Bohdan T. Woronowicz podkreśla, że

do najbardziej rozpowszechnionych w Polsce (poza alkoholem, lekami, tytoniem) substancji psychoaktywnych należą pochodne makowca, czyli opioidy (opiaty). Działają one przeciwbólowo i poprzez redukcję lęku dają uczucie spokoju, a niekiedy euforii ${ }^{24}$.

Można tu zakwalifikować: heroinę, morfinę, kodeinę, kompot, mlecz$\mathrm{ko}^{25}$. Idylliczne i błogie uczucie rozluźnienia, niekiedy stan euforii, dają osobie zażywającej złudne poczucie, iż wypracowała ona sobie nowy sposób walki ze stresem. Opioidy mogą być przyjmowane zarówno w formie doustnej (kompot, proszek, tabletki), jak i dożylnej (morfina, makiwara, heroina) wywołując $\mathrm{w}$ organizmie jedną $\mathrm{z}$ dwóch charakterystycznych reakcji: pobudzenie bądź spowolnienie funkcji ruchowych i poznawczych ${ }^{26}$.

Analiza biochemiczna wykazała, że opiaty w połączeniu z receptorami opatowymi, zlokalizowanymi w różnych częściach ludzkiego ciała (największe skupiska występują $\mathrm{w}$ obszarach mózgu, odpowiedzialnych za odczuwanie bólu i uczucia ${ }^{27}$ ), działają hamująco na procesy zachodzące w ośrodkowym układzie nerwowym ${ }^{28}$, w konsekwencji czego dochodzi do - jak wskazuje Zygmunt Madeja:

zwężenia źrenic, spowolnienia oddechu i senności. Na kilka godzin ból i lęk zostają zastąpione błogim uczuciem przyjemności ${ }^{29}$. Wywołuje to silne stany afektywne głę-

${ }^{23}$ Cz. Ciekiera, Ryzyko uzależnień, Lublin 2001, s. 19.

24 B.T. Woronowicz, Uzależnienia: geneza, terapia, powrót do zdrowia, s. 425.

${ }^{25}$ Cz. Ciekiera, Ryzyko uzależnień, s. 19.

26 B.T. Woronowicz, Uzależnienia: geneza, terapia, powrót do zdrowia, s. 425-426.

27 M.E.P. Seligman, Psychopatologia, t. 2, Warszawa 1994, s. 79.

${ }^{28}$ Z. Madeja, Uzależnienia od substancji psychoaktywnych, s. 271.

29 Tamże, s. 274. 
bokiego uciszenia, niewrażliwości na ból oraz euforii (...) przypominające poczucie bezpieczeństwa siedmiomiesięcznego płodu w łonie matki30.

Badania Czesława Ciekiery dowiodły, że „do osób najczęściej zażywających opiaty należą ludzie skłonni do nawyków, nałogów, labilni emocjonalnie, łatwo pobudliwi, trudno znoszący różne trudności fizyczne i psychiczne, zbyt wrażliwi, niezrównoważeni". Narkotyk spełnia więc w ich przypadku funkcję regulacyjną, redukując utrzymujące się na zbyt wysokim poziomie uczucie dyskomfortu. Jednocześnie, wzrastającej permanentnie potrzebie przyjęcia tej psychoaktywnej substancji towarzyszy obniżenie poziomu pozytywnych doznań, co w konsekwencji prowadzi do uzależnienia.

Wyniki badań przeprowadzone w 2009 roku wśród Polaków znajdujących się pomiędzy 15. a 64. rokiem życia, z użyciem metody punktu odniesienia (punkt odniesienia stanowiła liczba osób leczonych stacjonarnie oraz ambulatoryjnie $\mathrm{w}$ związku z uzależnieniem od opiatów), ujawniły, że liczba osób uzależnionych od opioidów mieściła się w szerokim przedziale 10444 19 794, natomiast wartość średnia wynosiła 15119 osób31. Należy zaznaczyć - odwołując się do wyników analogicznych badań wykonanych w roku 2005 (uzależnieni od opiatów znaleźli się w przedziale 25000 - 29 000) - że jest to tendencja spadkowa ${ }^{32}$.

\section{Nikotynizm}

Kolejną strategię eliminowania stresu wykraczającą poza granice norm zdrowotnych stanowi nikotynizm. Zgodnie z definicją sformułowaną przez Międzynarodową Statystyczną Klasyfikację Chorób i Problemów Zdrowia (ICD-10), uzależnienie od tytoniu to „zespół objawów behawioralnych, fizjologicznych i psychicznych, które są skutkiem systematycznego używania tej substancji"33. Tytoń to roślina zawierająca różnorodne alkaloidy, przede wszystkim nikotynę ${ }^{34}$. Jest to substancja silnie uzależniająca. Stanowi jeden z 4000 związków chemicznych wchodzących w skład papierosa ${ }^{35}$. Jej specyfika opiera się na pobudzaniu ośrodka nagrody w mózgu, poprzez oddzia-

${ }^{30}$ M.E.P. Seligman, Psychopatologia, s. 80.

${ }^{31}$ J. Sierosławski, Oszacowanie liczby problemowych użytkowników opioidów w Polsce, Alkoholizm i Narkomania, 2012, 4, s. 352, http://www.ipin.edu.pl/ain/aktualne/2012/12/AiN_42012_Sieroslawski.pdf, [dostęp: 10.06.2014].

32 Tamże, s. 353.

33 Z. Pużyński, Klasyfikacja Zaburzeń Psychicznych i Zaburzeń Zachowania w ICD-10, Kraków 2000, s. 73.

${ }^{34}$ Cz. Ciekiera, Ryzyko uzależnień, s. 9.

${ }^{35}$ A. Augustynek, Jak walczyć z uzależnieniami? s. 59. 
ływanie na receptory nikotynowe, znajdujące się m.in. w obwodowym układzie nerwowym, jak i w ciałach komórkowych układu sympatycznego i parasympatycznego. Oddziałuje ona więc na te receptory, "które sprawiają, że czujemy się tak dobrze, jak zawsze, gdy zrobimy coś tak, jak należy"36. Zatem, zażywanie nikotyny zwiększa wydzielanie dopaminy, która jak podkreśla Andrzej Augustynek:

daje uczucie zadowolenia po zapaleniu papierosa, co potęguje nałóg. Gdy poziom dopaminy spada, pojawia się wewnętrzny niepokój, lęk, a nawet depresja. By tego uniknąć, palacz ponownie sięga po papierosa. (...) Dlatego też uzależnienie od papierosów często nazywa się nikotynizmem ${ }^{37}$.

Nikotyna dając złudne uczucie przyjemności i odprężenia, motywuje osoby zestresowane do ponownego sięgnięcia po tego rodzaju używkę.

Czesław Ciekera podkreśla, że

konsumpcja tytoniu (...) pomaga pokonać barierę lęku czy nieśmiałości. Ludzie palą $\mathrm{z}$ powodu złego nastroju, nudy, ze zmartwienia (...). Wymienione motywy ujawniają, że sięganie po papierosa jest związane z frustracją określonej potrzeby, przeżywanymi trudnościami czy stresem ${ }^{38}$.

Można zatem wnioskować, że jedną z głównych motywacji, która zaimplikowała chęć sięgnięcia po pierwszego papierosa było owe pragnienie wyeliminowania dyskomfortu psychicznego. Przekierunkowanie uwagi ze stresora na bodziec potencjalnie przyjemniejszy doprowadziło - w wyniku warunkowania instrumentalnego - do wykształcenia mechanizmu uzależnienia. Papieros stał się atrybutem bezpieczeństwa i poczucia kontroli nad sytuacją.

Zgodnie z wynikami badań przeprowadzonych przez Centrum Badania Opinii Społecznej, w roku 2012 około 31\% dorosłych Polaków paliło papierosy, przy czym mężczyźni (40\%) sięgali po nie dwukrotnie częściej niż kobiety (23\%). Najniższy poziom uzależniania wykazały osoby znajdujące się powyżej 65. roku życia (13\%) oraz te, które znalazły się w okresie wczesnej dorosłości, tj. 25-34 rok życia (26\%). Z kolei, najwyższy poziom uzależnienia przypadł na wiek średni, tj. 35-54 rok życia $(40 \%)^{39}$.

Wielokrotnie przeprowadzone i potwierdzone wnioski z badań ujawniły, że

${ }^{36}$ Z. Madeja, Uzależnienia od substancji psychoaktywnych, s. 251.

37 A. Augustynek, Jak walczyć z uzależnieniami? s. 59.

38 Cz. Ciekiera, Ryzyko uzależnień, s. 67.

39 Postawy wobec palenia papierosów, Centralny Ośrodek Badania Opinii Społecznej, http://www.cbos.pl/SPISKOM.POL/2012/K_107_12.PDF [dostęp: 10.06.2014]. 
nikotyna ma bardziej szkodliwy wpływ na zdrowie ludzi, których eliminuje spośród żywych, niż wszystkie inne środki psychotropowe razem wzięte - z heroiną, kokainą i alkoholem włącznie ${ }^{40}$.

Nie dziwi zatem fakt wysokiej śmiertelności osób, które ją zażywają. Zgodnie z badaniami Światowej Organizacji Zdrowia z 2005 roku, około 5,4 mln osób umarło na skutek powikłań chorobowych wywołanych przez nikotynę. Do najczęstszych schorzeń można zakwalifikować choroby układu krążenia oraz nowotwory płuc, okolic przełyku. Osłabieniu ulega także system odpornościowy ${ }^{41}$.

\section{Pracoholizm}

Na podstawie wyników badań umieszczonych w artykule Eweliny Sęk wynika, że „przeciętny Polak pracuje najdłużej w Europie: 41,6 godzin tygodniowo" 42 . Paradoks zjawiska wskazuje na zaburzenie proporcji pomiędzy czasem wykonywanej pracy a sytuacją ekonomiczną naszego kraju. Doskonale obrazują to państwa kultury anglosaskiej (Irlandia, Anglia) czy kraje południowe (Włochy), których znaczna przewaga gospodarcza nad Polską jest tożsama ze znacznie mniejszą liczbą godzin spędzanych w miejscu pracy. Jak podkreśla Jan Terelak, intensywny rozwój pracoholizmu pojawił się pod koniec wieku XX. Praca zawodowa stała się swoistą odskocznią od życia prywatnego, w tym również rodzinnego. Wytworzył się więc nowy sposób na życie, będący jednym z licznych „trendów” popkultury. W niniejszym zestawieniu niekonstruktywnych metod radzenia sobie ze stresem zajmuje pierwsze miejsce pod względem "nowości”43. Jednak już od kilku lat zbiera swoje okrutne żniwo wśród ludzi na całym świecie, a w szczególności w Japonii, gdzie nierzadko kończy się śmiercią ${ }^{44}$. W perspektywie badań międzynarodowych pracoholizm definiowany jest jako

zaburzenie obsesyjno-kompulsyjne, przejawiające się przymuszaniem samego siebie do pracy, niemożnością regulowania własnych nawyków związanych z pracą i nadmiernym zaangażowaniem w nią, aż do zaniedbania innych głównych czynności życiowych ${ }^{45}$.

${ }^{40}$ Z. Madeja, Uzależnienia od substancji psychoaktywnych, s. 251.

41 Tamże, s. 60.

42 E. Sęk, Pracoholizm, http://wwww.fidesetratio.com.pl/Presentations0/pracoholizm.pdf, [dostęp: 15.03.2013].

43 J. Terelak, Cztowiek i stres, s. 204.

${ }^{44}$ A. Augustynek, Jak walczyć z uzależnieniami? s. 94.

${ }^{45}$ E. Łuczak, Nowe oblicza uzależnień, Olsztyn 2009, s. 151. 
Pracoholizm jest więc zjawiskiem bardzo silnie odciskającym swoje piętno we wszystkich sferach funkcjonowania człowieka.

W literaturze przedmiotu panuje wysoki poziom zróżnicowania pod względem danych odnoszących się do źródeł pracoholizmu. Interesujący pogląd na omawiane zjawisko prezentuje psychiatra Melvin L. Kohn, zdaniem którego pracoholizm jest strategią radzenia sobie ze stresem, a nie jego skutkiem. Powstaje w odpowiedzi na "problemy emocjonalne” związane z zaburzeniami lękowymi oraz „depresjami nasilanymi przez cechy obsesyjno-kompulsywne". Można więc powiedzieć, że podłożem do podjęcia tego typu działań będzie „depresja o średnim natężeniu”46. Doskonałe uzupełnienie niniejszej koncepcji prezentuje $\mathrm{w}$ artykule Pracoholizm - istota, konsekwencje i uwarunkowania Lucyna Golińska, podkreślająca, że

$\mathrm{w}$ pracoholizmie praca staje się skutecznym mechanizmem regulacji emocji, środkiem wywołującym pozytywne emocje lub redukującym wcześniej doświadczane negatywne - generalnie więc polepsza stan emocjonalny. Wraz z pozytywną modyfikacją nastroju praca staje się sposobem radzenia sobie ze stresem: podjęcie pracy oznacza podwyższenie poziomu aktywacji, zwiększa energię, a równocześnie daje zdystansowanie do tego co poza nią i pośrednio uspokaja ${ }^{47}$.

Zyskuje więc miano „bezpiecznej oazy”, do której człowiek chętnie powraca, pragnąc odzyskać utraconą równowagę (tak psychiczną, jak i fizjologiczną). Osoby nadmiernie angażujące się w pracę zawodową, celem odwrócenia uwagi od problemów będących dla nich źródłem stresu Wayn Oates (twórca terminu pracoholizm) określa mianem pracoholików eskapistów (escapist workaholic) ${ }^{48}$ (za B. Dudek). Badania Kamili Wojdyło przeprowadzone $\mathrm{w}$ grupie 627 respondentów ujawniły, że u podłoża pracoholizmu znajdują się specyficzne uwarunkowania osobowościowe, przejawiające się trudnościami $\mathrm{w}$ zakresie efektywnej regulacji emocjonalnej ( $\mathrm{w}$ tym rozładowywania napięć $)^{49}$.

Biorąc pod uwagę motywy stosowania tego typu oddziaływań, można wnioskować, że pracoholizm podobnie jak pozostałe formy uzależnień pozwala człowiekowi na „odwrócenie uwagi od stresora" 50 . Całkowita koncen-

${ }^{46}$ L. Golińska, Pracoholizm. Uzależnienie czy pasja? Warszawa 2008, s. 13.

${ }^{77}$ L. Golińska, Pracoholizm - istota, konsekwencje i uwarunkowania, Folia Psychologica, 2010, 14, s. 100

48 B. Dudek, Pracoholizm - szkodliwy skutek nadmiernego zaangażowania w pracę, Medycyna Pracy, 2008, 59(3), s. 250.

${ }^{49}$ K. Wojdyło, Pracoholizm - poznawczo-behawioralny model psychoterapii, Nauka, 2013, 4, s. 129, http://work-passion.eu/wp-content/uploads/2013/12/KWojdylo_Nauka_art_2_2103. pdf, [dostęp: 29.05.2014].

${ }^{50}$ I. Heszen-Niejodek, Stres i radzenie sobie - główne kontrowersje, s. 20. 
tracja na pracy zawodowej pozwala osobom tak funkcjonującym nie tyle na zrelaksowanie się, co po prostu stanowi atrybut mentalnej odskoczni czy też „bocznej furtki”, która pozwala na niepostrzeżoną ucieczkę od wywołujących niepokój i lęk problemów życia prywatnego.

\section{Kultura skoku adrenaliny i ryzyka - stymulacja jako specyficzna forma strategii radzenia sobie ze stresem}

Kultura skoku adrenaliny i ryzyka jako egzemplifikacja obecnie panujących standardów życia społecznego stanowi ideologiczne podstawy do podjęcia analizy nad strategiami radzenia sobie ze stresem $w$ kontekście dokonujących się przemian cywilizacyjnych. We współczesnym społeczeństwie konsumpcji najwyższą wartość stanowi ilość (wrażeń), zaś jakość wydaje się mniej znacząca. Im bardziej doznania są zintensyfikowane i niebezpieczne, tym większe walory zyskują w oczach odbiorcy. Nie stanowią więc obiektu pożądania "codzienne, zwykłe przyjemności"51. Kluczowym terminem staje się pojęcie adrenaliny, neurohormonalnego przekaźnika produkowanego przez nadnercza w warunkach silnego pobudzenia organizmu ${ }^{52}$. John Tomlinson $\mathrm{w}$ celu trafnego zobrazowania społecznych doświadczeń wszechobecnego "pędu" nawiązuje do teorii impresjonizmu socjologicznego (socjological impressionism) Georga Simmela. Podkreśla, że uchwycenie dynamiki rzeczywistości społecznej staje się niezwykle trudnym wyzwaniem ${ }^{53}$. Jak wskazuje Zbyszko Melosik, „ludzie szukają sposobów na skok adrenaliny i gonią za ekstremalnymi doznaniami" 54 , których źródłem może być np. „kierowanie bolidem $w$ wyścigach Formuły I lub sporty ekstremalne" 55 . Z badań ${ }^{56}$ przeprowadzonych na przełomie 2012/2013 roku przez Sponsoring Monitor ARC Rynek i Opinia wynika, że 10\% respondentów uprawia sporty ekstremalne, przy czym $65 \% \mathrm{z}$ nich stanowią mężczyźni w wieku od 18. do 34. roku życia (55\%) 57 . Należy z pełną tego słowa świadomością zaak-

51 Z. Melosik, Wielokulturowość, globalizacja, [w:] Teoria i praktyka edukacji wielokulturowej, red. Z. Melosik, Kraków 2007, s. 64.

52 P. Chocholska, Sporty ekstremalne i uzależnienie od adrenaliny, http://www.psychotekst. $\mathrm{pl} /$ artykuly.php? $\mathrm{nr}=118$, [dostęp: 12.04.2013].

53 J. Tomlinson, The Culture of Speed: The Coming of Immediacy, SAGE Publications 2007, s. 7.

${ }^{54}$ Z. Melosik, Wielokulturowość, globalizacja, s. 64.

55 Tamże, s. 65.

56 Badania zostały przeprowadzone wśród 1808 mieszkańców Polski w wieku 15-65 lat, metodą bezpośrednich wywiadów kwestionariuszowych.

57 Polak ekstremalnie, https://epanel.pl/?p=news\&p2=25, [dostęp: 10.06.2014]. 
centować, jak istotną rolę owe ekstremalne sporty zaczynają odgrywać $\mathrm{w}$ życiu jednostek poszukujących intensywnych doznań. Popularną formę tego typu rozrywek stanowi Downhill, specyficzna odmiana kolarstwa górskiego. Źródłem silnego pobudzenia staje się tutaj zjazd po stromych stokach, nierzadko opatrznych licznymi wyżłobieniami, uskokami oraz korzeniami drzew. Popularne stają się także „wspinaczki po lodospadach, spływy rwącymi rzekami, loty na paralotniach na wysokości kilku tysięcy metrów". Szukając przyczyn powstawania tego typu motywacji oraz dążeń, należałoby zwrócić uwagę na wypowiedź Janusza Czapińskiego, który podkreśla, że współczesny człowiek odczuwa ogromną potrzebę „balansowania na krawędzi”, ponieważ jego życie jest "łatwe i nudne". Takie spostrzeżenie kieruje w stronę wysoko sytuowanych $\mathrm{w}$ hierarchii społecznej grup, nazywając ich potrzebę pobudzenia „polowaniem na emocje”. Jednocześnie wskazuje, że szczególnie pożądaną dla nich formę będą stanowiły intensywne, fizyczne doznania. To one stworzą realne szanse na sfinalizowanie pragnień $\mathrm{w}$ postaci rzeczywistych i namacalnych źródeł pobudzenia ${ }^{58}$. W tym kontekście można interpretować podejmowanie przez jednostkę sportów ekstremalnych jako wyraz pewnego rodzaju uzależnienia od tej formy aktywności zarezerwowanej wyłącznie dla grupy osób o odpowiednio wysokim statusie socjoekonomicznym 59 .

"Wejście w realną ekstremalność" może być niekiedy ograniczone deficytami jednostki w wymiarze fizycznym lub/i materialnym. Wówczas strategią zaradczą staje się redukcja "poszukiwanych ekstremalnych doznań", czego odzwierciedlenie może stanowić np. brawurowa jazda samochodem. Chęć uzyskania maksymalnych doznań przy minimalnym poziomie zaangażowania Zbyszko Melosik określa jako ekstremalność „łatwo spreparowaną we własnym umyśle". Doskonałym stymulatorem pobudzenia może być projekcja filmów potocznie zwanych dreszczowcami bądź horrorami, jak również uczestnictwo $\mathrm{w}$ grach komputerowych. O ile takie zachowania mieszczą się $w$ ramach norm społecznych, o tyle istnieją jeszcze inne, niezgodne z obowiązującymi wzorcami moralnymi działania zmierzające do osiągnięcia stanu pobudzenia. Ich konfliktowa natura uwarunkowana jest przede wszystkim brakiem konwencjonalności oraz rosnącym zagrożeniem dla zdrowia lub życia. "Stymulatory mózgu” - nazwane tak przez badacza "przesuwają granicę ekstremalności do granicy życia i śmierci”. W większości przypadków są to substancje psychoaktywne (narkotyki) wywołujące efekt halucynogenny.

${ }^{58}$ K. Olejnik, Uzależnieni od adrenaliny, http://www.wprost.pl/forum//5549/, [dostęp: 12.04.2013].

${ }^{59}$ R. Makarowski, Granice ryzyka. Paradygmat psychologiczny, Kraków 2008, s. 47. 
Jednym z elementów kultury skoku adrenaliny i ryzyka staje się podejmowanie ryzykownych zachowań seksualnych. Człowiek kierując się atawistycznym pożądaniem, hołdującym „zasadzie natychmiastowości” podejmuje kontakty seksualne „bez zabezpieczenia z przypadkowym partnerem/ przypadkową partnerką". Biegnąc ścieżką trywialnych założeń konsumpcjonizmu, wzmacnia swoje popędy używając wspomnianych już wcześniej „stymulatorów mózgu"60. W konsekwencji, owe substancje takie jak „alkohol i narkotyki obniżają zdolność samokontroli, pozbawiają zahamowań, dodają pewności siebie, $\mathrm{w}$ pierwszej fazie wzmagają pociąg seksualny oraz sprzyjają zawieraniu przypadkowych znajomości i prostytucji" 61 . W rezultacie cel, jakim jest "maksymalizacja wrażeń" 62 zostaje osiągnięty, a pragnienie niebezpiecznego seksu zostaje zaspokojone. Zbyszko Melosik określa to mianem „rosyjskiej ruletki”. Utrata życia lub nie. Prawdopodobieństwo zakażenia wirusem HIV przyjmuje formę świadomej prowokacji i nie jest bynajmniej podyktowane brakiem kompetencji w zakresie wiedzy dotyczącej zdrowia seksualnego. „Igranie ze śmiercią” 63 samo w sobie staje się źródłem pobudzenia i fantastyczną dawką adrenaliny. Wyniki badań przeprowadzonych $\mathrm{w}$ grupie 254 kobiet, mieszkanek dużych aglomeracji miejskich (powyżej 200 tysięcy mieszkańców) o rozpiętości wiekowej pomiędzy 19. a 48. rokiem życia ujawniły, że ryzykowne zachowania seksualne stały się doświadczeniem aż 13,2\% respondentek ${ }^{64}$. Z kolei, raport sporządzony na podstawie wyników badań Zbigniewa Izdebskiego i Polpharmy "Seksualność Polaków 2011" wykazał, że 12\% kobiet oraz 21\% mężczyzn w przedziale wiekowym 15-59 lat przynajmniej raz podjęło ryzykowane zachowania seksualne ${ }^{65}$.

Ideologicznych wzorców stanowiących poniekąd o impersonalnej aprobacie społecznej należałoby poszukiwać w zjawisku seksualizacji kultury, którą w książce Mainstreaming Sex: The Sexualisation of Western Culture analizuje Feona Attwood, podejmując dyskurs na temat współczesnych form eksponowania cielesności $\mathrm{w}$ kulturze i ich wpływu na poszczególne sfery

${ }^{60}$ Z. Melosik, Wielokulturowość, globalizacja, s. 65.

${ }^{61}$ B. Woynarowska, Edukacja zdrowotna, s. 373.

62 Z. Melosik, Młodzież i styl życia: Paradoksy pop-tożsamości, [w:] Młodzież, styl życia i zdrowie. Konteksty i kontrowersje, red. Z. Melosik, Poznań 2000, s. 34.

63 Z. Melosik, Wielokulturowość, globalizacja, s. 66.

${ }^{64}$ A. Machaj i in., Ryzykowne zachowania kobiet w okresie prokreacyjnym, Nowiny Lekarskie, 2010, 79(1), s. 28.

65 Badanie Zbigniewa Izdebskiego i Polpharmy: Seksualność Polaków, 2011, http://www. termedia.pl/-Badanie-Zbigniewa-Izdebskiego-i-Polpharmy-Seksualnosc-Polakow-2011-,5152. html, [dostęp: 10.06.2014]. 
życia człowieka ${ }^{66}$. O odczuwaniu intensywnej potrzeby wzrostu adrenaliny i ryzyka niezbędnej do redukcji napięcia w sferze seksualności może świadczyć fakt, że „seks i życie seksualne odarte dziś są z jakiejkolwiek intymności i prywatności". Upowszechnienie czegoś, co w przeszłości uważano za wyjątkowe i intymne doprowadziło do swoistej instrumentalizacji tej sfery życia. Popęd seksualny przestał stanowić temat tabu, a współżycie dwojga ludzi przestało ograniczać się wyłącznie do odczuwania wyższych emocji np. miłości. Seks (w odniesieniu do podjętej przeze mnie problematyki) został zdegradowany do pozycji „procesów fizjologicznych" ${ }^{67}$. W kontekście cywilizacyjnych przemian stał się sposobem redukcji napięcia, wyłączając jednocześnie konieczność istnienia pierwiastka emocjonalnej bliskości dwojga ludzi.

Człowiek chcąc poskromić lęk oraz towarzyszące mu każdego dnia (np. $\mathrm{w}$ pracy) napięcie i zdenerwowanie, może poszukiwać niespecyficznych doznań, które umożliwiłyby mu odreagowanie wszelkich niepowodzeń. Osoby namiętnie poszukujące silnych wzmocnień i wszelkiego rodzaju podniet, balansując na granicy ryzyka, "oszukują lęk, siłują się z nim”. Dobrowolne igranie $\mathrm{z}$ niebezpieczeństwem oraz bezpośrednia konfrontacja $\mathrm{z}$ zagrożeniem pozwala, $\mathrm{w}$ rozumieniu tychże osób, zminimalizować wszelkie napotkane dotychczas stresory, zarówno te pojawiające się w życiu prywatnym, jak i zawodowym. Mogą one być ugruntowane na bazie przeświadczenia, że to „kultura nakłada na nas sporo ograniczen". Wspomniane ograniczenia mogą generować u niektórych osób pragnienie bycia wyzwolonym z wszelkich więzów powinności, które w efekcie prowadzą do poczucia lęku czy po prostu odczuwania stresu ${ }^{68}$. Uwzględniając psychologiczne koncepcje pobudliwości, warto podkreślić istnienie tzw. progów pobudzenia. Należy pamiętać, że mają one wymiar wysoce indywidualny, charakterystyczny dla danej jednostki ${ }^{69}$.

\section{Zakończenie}

Niniejszy artykuł odwołując się do badań zawartych w literaturze przedmiotu, stanowi próbę przeanalizowania i interpretacji najbardziej popularnych, niekonwencjonalnych form i metod redukowania/minimalizowania poziomu odczuwanego przez jednostkę stresu. Nie wyczerpuje on

${ }^{66}$ Zob. F. Attwood, Mainstreaming Sex: The Sexualisation of Western Culture, I.B. Tauris, 2009.

67 Z. Melosik, Młodzież i styl życia: Paradoksy pop-tożsamości, s. 40.

68 P. Chocholska, Sporty ekstremalne i uzależnienie od adrenaliny.

69 R. Makarowski, Granice ryzyka. Paradygmat psychologiczny, s. 45. 
jednak w pełni wszystkich możliwych strategii i koncepcji stanowiących o negatywnych sposobach eliminowania stresorów. Moim celem było wykazanie oddziaływań występujących w populacji z dużą częstotliwością, zwracając szczególną uwagę na ich mechanizm oraz konsekwencje zdrowotne (fizyczne i psychiczne). Analizując zróżnicowane pod względem treści i przyjętych w społeczeństwie norm niekonwencjonalne strategie zaradcze, należy pamiętać, że człowiek może przyjmować wzorce pochodzące z każdej z omówionych przeze mnie grup, balansując nad przepaścią uzależnienia. Należy podkreślić, że wspomniane strategie przenikają się wzajemnie, stanowiąc tym samym o indywidualnych, specyficznych dla danej jednostki negatywnych sposobach redukcji stresorów. Ich dobór jest $\mathrm{w}$ znacznym stopniu determinowany poprzez pierwiastek kulturowy, którego obraz staje się atrybutem panujących $\mathrm{w}$ populacji trendów, będących niejako ideologicznym schematem postępowania większości jego odbiorców. Obecność nowoczesnych technologii oraz procesy globalizacji sprawiają, że człowiek niejako z perspektywy widza obserwuje zmieniającą się niczym w kalejdoskopie rzeczywistość, sięgając śmiało po jej kuszące formą i treścią wytwory. Można zatem wnioskować, że wszechobecność napięcia, zdenerwowania, niepokoju, które nazbyt często stanowią synonim „pędzącej kultury naszych czasów", będzie wzmagać w jednostce chęć odnalezienia łatwo dostępnych, chociaż niekoniecznie bezpiecznych dla zdrowia i/lub życia "środków" uśmierzających psychiczny i fizyczny dyskomfort.

\section{BIBLIOGRAFIA}

Attwood F., Mainstreaming Sex: The Sexualisation of Western Culture, I.B. Tauris, 2009.

Augustynek A., Jak walczyć z uzależnieniami? Warszawa 2011.

Bishop G.D., Psychologia zdrowia: zintegrowany umyst i ciało, Warszawa 2000.

Chocholska P., Sporty ekstremalne $i$ uzależnienie od adrenaliny, http://www.psycho tekst.pl/artykuly.php?nr=118, [dostęp: 12.04.2013].

Ciekiera Cz., Ryzyko uzależnień, Lublin 2001.

Cierpiałkowska L., Ziarko M., Psychologia uzależnień - alkoholizm, Warszawa 2010.

Dudek B., Pracoholizm - szkodliwy skutek nadmiernego zaangażowania w prace, Medycyna Pracy, 2008, 59(3).

Golińska L., Pracoholizm. Uzależnienie czy pasja? Warszawa 2008.

Golińska L., Pracoholizm - istota, konsekwencje i uwarunkowania, Folia Psychologica, 2010, 14.

Heszen-Niejodek I., Stres i radzenie sobie - główne kontrowersje, [w:] Człowiek w sytuacji stresu: Problemy teoretyczne i metodologiczne, red. I. Heszen-Niejodek, Z. Ratajczak, Katowice 2000.

Heszen-Niejodek I., Styl radzenia sobie ze stresem jako indywidualna zmienna wptywajaca na funkcjonowanie w sytuacji stresowej, [w:] Osobowość a ekstremalny stres, red. J. Strelau, Gdańsk 2004. 
Izdebski Z. i Polpharma, Seksualność Polaków, 2011, http://www.termedia.pl/-BadanieZbigniewa-Izdebskiego-i-Polpharmy-Seksualnosc-Polakow-2011-,5152.html, [dostęp: 10.06.2014].

Karski J., Praktyka i teoria promocji zdrowia, Warszawa 2007.

Łosiak W., Psychologia stresu, Warszawa 2008.

Łuczak E., Nowe oblicza uzależnień, Olsztyn 2009.

Machaj A. i in., Ryzykowne zachowania kobiet w okresie prokreacyjnym, Nowiny Lekarskie, 2010, 79(1).

Makarowski R., Granice ryzyka. Paradygmat psychologiczny, Kraków 2008.

Melosik Z., Młodzież i styl życia: Paradoksy pop-tożsamości, [w:] Młodzież, styl życia i zdrowie. Konteksty i kontrowersje, red. Z. Melosik, Poznań 2001.

Melosik Z., Globalna mtodzież i styl życia, [w:] Teoria i praktyka edukacji wielokulturowej, red. Z. Melosik, Kraków 2007.

Melosik Z., Wielokulturowość, globalizacja, [w:] Teoria i praktyka edukacji wielokulturowej, red. Z. Melosik, Kraków 2007.

Olejnik K., Uzależnieni od adrenaliny, http://www.wprost.pl/forum//5549/, [dostęp: 12.04.2013].

Polak ekstremalnie, https://epanel.pl/?p=news\&p2=25, [dostęp: 10.06.2014].

Pospiszyl I., Patologie społeczne, Warszawa 2008.

Postawy wobec palenia papierosów, Centralny Ośrodek Badania Opinii Społecznej, http://www.cbos.pl/SPISKOM.POL/2012/K_107_12.PDF [dostęp: 10.06.2014].

Pużyński Z., Klasyfikacja Zaburzeń Psychicznych i Zaburzeń Zachowania w ICD-10, Kraków 2000.

Seligman M.E.P., Psychopatologia, t. 2, Warszawa 1994.

Seyle H., Stres okietznany, Warszawa 1977.

Sęk E., Pracoholizm, http://www.fidesetratio.com.pl/Presentations0/pracoholizm.pdf, [dostęp: 15.03.2013].

Shevlin M., McGuigan K., Final Report, Mediating effects of mental health problems in the stress alcohol relationship, http://alcoholresearchuk.org/downloads/finalReports/ AERC_FinalReport_0077.pdf, [dostęp: 03.06.2014].

Sierosławski J., Oszacowanie liczby problemowych użytkowników opioidów w Polsce, Alkoholizm i Narkomania, 2012, 4, http://www.ipin.edu.pl/ain/aktualne/2012/12/AiN_42012_Sieroslawski.pdf, [dostęp: 10.06.2014].

Siuta J., Stownik psychologii, Kraków 2005.

Terelak J., Cztowiek i stres, Bydgoszcz-Warszawa 2008.

Tomlinson J., The Culture of Speed: The Coming of Immediacy, SAGE Publications 2007.

Wojdyło K., Pracoholizm - poznawczo-behawioralny model psychoterapii, Nauka, 2013, http://work-passion.eu/wpcontent/uploads/2013/12/KWojdylo_Nauka_art_2_2103.pdf, [dostęp: 29.05.2014].

Woronowicz B.T., Uzależnienia: geneza, terapia, powrót do zdrowia, Warszawa 2009.

Woynarowska B., Edukacja zdrowotna, Warszawa 2008. 